\title{
SMARCD3 wt Allele
}

National Cancer Institute

\section{Source}

National Cancer Institute. SMARCD3 wt Allele. NCI Thesaurus. Code C52115.

Human SMARCD3 wild-type allele is located within 7q35-q36 and is approximately $38 \mathrm{~kb}$ in length. This allele, which encodes SWI/SNF-related matrix-associated actin-dependent regulator of chromatin subfamily $\mathrm{D}$, member 3 protein, is involved in both transcriptional activation and chromatin organization. 